\title{
Cultural Importance and Livelihood Contribution of Turanala and Talkandla Wetlands in Gorakhpur, India
}

\section{Pratap Narain Singh and Anil K Dwivedi*}

Department of Botany, DDU Gorakhpur University, Gorakhpur-273009, UP, India

In India, in the state of Uttar Pradesh the distribution of wetlands is $1.24 \mathrm{~m}$ ha [1]. Himalaya and monsoon play the dominant role in determining the nature of wetlands in tropical Asia. There are two distinct eco-climatic zones parallel to sub-Himalayan tracts in north India viz., Bhabhar and Terai (wetlands). Bhabhar is rather narrow and relatively dry strip having low water table, while the Terai is much more extensive and wet. The Terai landscape is a tract between Sarju river and the foothills of the Himalayas covering 11 districts of north-eastern Uttar Pradesh, including Gorakhpur, the region is known for its unique biodiversity and high productivity [2]. For the analysis of wetland communities (during 2012-2014) two wetlands, Turanala (Figure 1), a riverine wetland (Site-I) and Talkandala Wetlands (Figure 2), a lacustrine wetland (Site-II) were selected in Gorakhpur. The study sites lie between $26^{\circ} 13^{\prime}$ to $27^{\circ} 29^{\prime} \mathrm{N}$ and $83^{\circ} 05^{\prime}$ to $83^{\circ} 56^{\prime} \mathrm{E}$ and are at an average elevation of 84 meter. The analysis has been made to the degree of disturbances which may occur in these wetlands.

Nearly all the civilizations established in the vicinity of some prominent water bodies, normally the rivers. As water is the essence of life, thus, all the need of water was accomplished and in addition the water was also used as a means of transportation. In the term of coexistence, the man started using all the biodiversity available in the water including flora and fauna. Further, dependency on the product of the water bodies increased exponentially. Most of the rituals, especially in India and in Hindu culture are associated with water and the water bodies. India is a nation in which the rivers are treated sacred and holy and often they are named as mother, such as Ma Gange. Bathing in the holy water and cremation after death in the Ganga is considered as the most pious ritual. Chhath pooja, a three day fast and worship of lord Sun is performed, while standing in water (Figure 3); this religious act cannot be performed without the water bodies. An attempt has been made to list the floral diversity of the two selected water bodies, in light of the entnobotanical importance for livelihood of the local people.

The community composition and distribution of species in the two wetlands showed that the species recorded in riverine wetland were

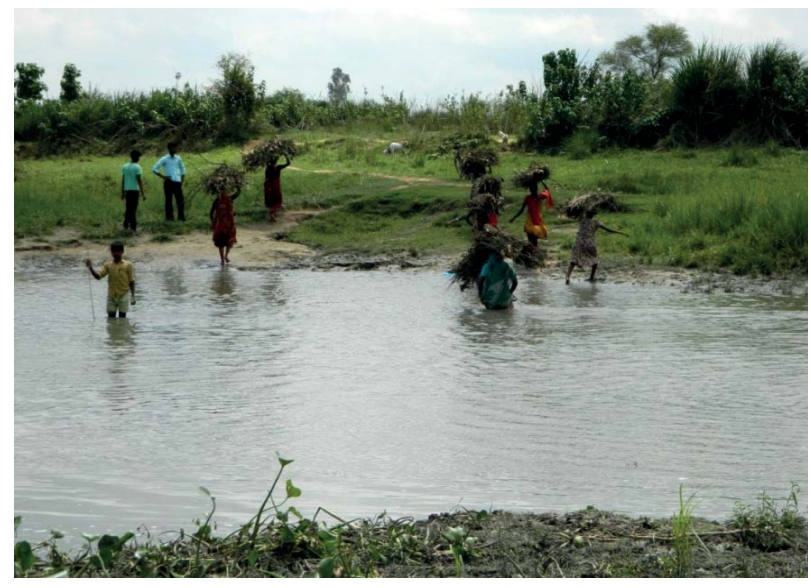

Figure 1: Human involvement in Turanala.

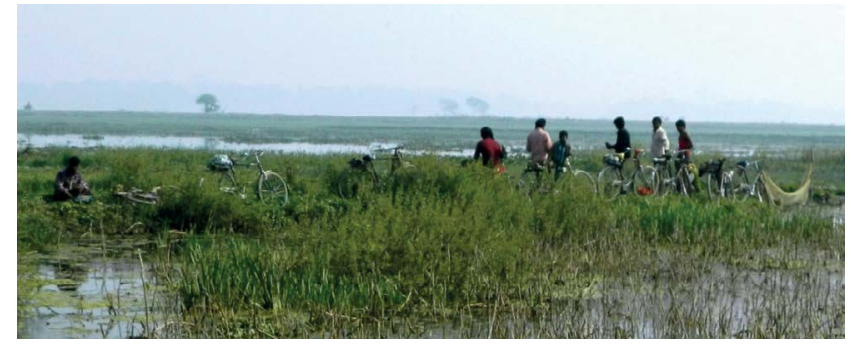

Figure 2: Harvestation in Talkandala.

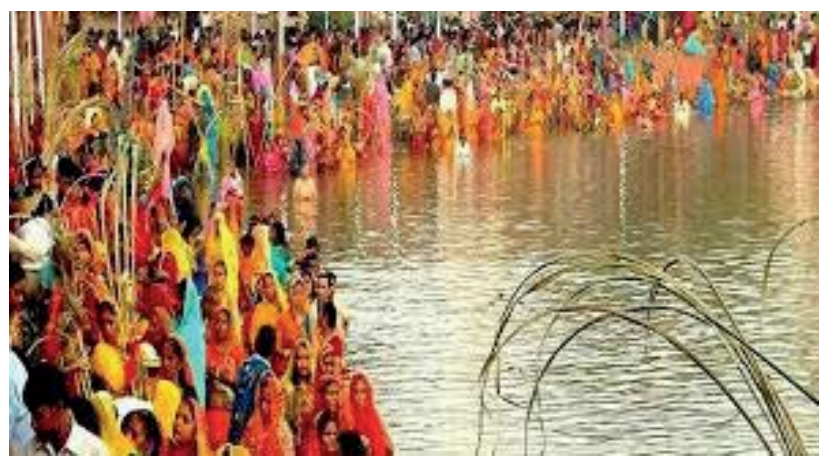

Figure 3: Gathering in Chhath Puja.

greater in number as compared to lacustrine wetland. The number of regeneration modes in wetland plants enabling a plastic response to changing environmental conditions e.g. Hydrilla verticillata, Potamogeton crispum and Vallisneria spiralis [3].

Higher IVI of species like Lemna minor, Ipomoea fistulosa, Nicotiana plumbaginifolia, Polygonum barbatum, Polygonum glabrum and Monochoria hastata at riverine site may be related to their response to fluctuations in water level. On the other hand, greater IVI of species like Eichhornia crassipes, Alternanthera philoxeroides, Cyanotis axillaris, Ipomoea aquatica, Potamogeton crispum and Sagittaria sagittifolia at lacustrine site, may be related to their characteristic growth pattern [3]. The rise and fall of water is a continuous stress for the stress tolerant perennials, such as Ipomoea fistulosa, Vetiveria zizanioides, Eugenia heyneana and Ficus heterophylla.

${ }^{*}$ Corresponding author: Dwivedi AK, Department of Botany, DDU Gorakhpur University, Gorakhpur-273009, UP, India, Tel: +91 - 0231 - 2609143; E-mail: anil.k.dwiwedi@gmail.com

Received July 19, 2016; Accepted August 12, 2016; Published August 19, 2016

Citation: Singh PN, Dwivedi AK (2016) Cultural Importance and Livelihood Contribution of Turanala and Talkandla Wetlands in Gorakhpur, India. Int J Waste Resour 6: 245. doi: 10.4172/2252-5211.1000245

Copyright: @ 2016 Singh PN, et al. This is an open-access article distributed under the terms of the Creative Commons Attribution License, which permits unrestricted use, distribution, and reproduction in any medium, provided the original author and source are credited. 
Citation: Singh PN, Dwivedi AK (2016) Cultural Importance and Livelihood Contribution of Turanala and Talkandla Wetlands in Gorakhpur, India. Int J Waste Resour 6: 245. doi: 10.4172/2252-5211.1000245

Page 2 of 2

The angiospermic flora of Terai landscape, as evident, has a great potential as plant resource. Nearly all the aquatic plants are used by the local people, in one or the other way. Figures 1 and 2 shows the community involvement for exploration and collection of the plants. Some plants are consumed as food, while others as fodder. Some plants are dried for their utilization as fuel. Some other plants are also used for making mats or as roof for the mud houses. According to Shashi and Dwivedi [4] the practices related to human habitation leading to urbanization, fishing, agriculture and the modern development are causing a fast shrinkage of wetlands and a number of species are continuously decreasing, sustainable utilization of the same should be promoted.

\section{References}

1. Dwivedi AK, Singh PN, Samuel CO (2015) Phenological Attributes of Angiospermic Flora in a Riverine Wetland of Gorakhpur. Research \& Reviews: Journal of Ecology 4: 1-11.

2. Prajapati UB, Dwivedi AK, Singh S (2013) Sustainable Utilisation of Aquatic Macrophyte for Waste Water Treatment. Advances in Plant Sciences 26: 443446.

3. Dwivedi AK, Singh PN, Samuel CO (2013) Phytosociological Analysis of Turanala, A Riverine Wetland of Gorakhpur, India. Life Sciences Leaflets 11: 101-112.

4. Shashi, Dwivedi AK (2008) Ganga Express Way - A path of wetland destruction Current Science 94: 840-841. 